\title{
Geography and Insecurity in Northern Nigeria
}

\author{
Jubril Babatunde, Jimoh \\ Department of Geography, Emmanuael Alayande College of Education, Oyo, Oyo State, Nigeria
}

*Corresponding Author: Jubril Babatunde, Jimoh, Department of Geography, Emmanuael Alayande College of Education, Oyo, Oyo State, Nigeria

\begin{abstract}
The security condition of Nigeria space has reached a worrisome altitude and it is now beacon on every Nigerian to chart a way out, the paper attempted to provide explanation on the downplay of geography which culminated in insecurity in northern Nigeria. It simultaneously explored effective understanding of the country's geography in addressing insecurity in the region. It ventured into literature survey to accomplish the set goal. It revealed that all the three geopolitical zones in the northern Nigeria were under intense insecurity with the operation of Boko Haram, farmer-herder criminality, terrorism and banditry, criminal gangs and jihadists crime. It also revealed the tactical strategies for criminality to include difficult terrains to state security, bombings, seizure and destruction of villages, kidnapping for ransom, armed robbery, pillage, forced displacement, abductions and sexual violence. In addition the factors that promoted banditry were cattle rustling, illicit artisanal gold mining, proliferation of Small Arms and Light Weapons (SALW), ethnic hate, religious bigotry, and territorial ambition among others. It highlighted the effects of criminality to include massive displacement of people, decline agricultural output, dwindling investment and increase outof-school children. Government had fought insecurity in northern Nigeria with "force-for-force", carrot-andstick approach and use of diplomacy and given amnesty. It was recommended that there should be well equipped armed forest guards with modern digital communication technology, operational of geopolitical zones as basis for planning policing, construction of physical barriers on the international borders and strategic spatial planning.
\end{abstract}

Keywords: Cattle rustling, Farmer/herder, Geography, Geopolitical zone, Insecurity, Kidnapping

\section{INTRODUCTION}

The Nigeria federation is complex when it is analysed by the politics of different spaces that made up the country. The geopolitical structuring of the country presently comprises six geopolitical zones of Northwest (Sokoto, Kebbi, Zamfara, Katsina, Kaduna, Kano and Jigawa states); Northeast (Borno, Bauchi, Gombe, Yobe, Adamawa and Taraba states); North central (Niger, Kwara, Kogi, Nasarawa, Plateau and Benue states); Southwest (Lagos, Ogun, Oyo, Ondo, Ekiti and Osun States); South south (Edo, Delta, Bayelsa, Rivers, Akwa-Ibom and Cross River); and Southeast (Anambra, Enugu, Imo, Abia and Ebonyi states). Power struggle among the six geopolitical zones has become intense which cannot be ruled out of the insecurity in the Nigeria system. One may then ask, is the restructuring from three regions (Northern, Western and Eastern) to four regions with the addition of Mid-western carved out of Western region, restructured to twelve states in 1967, nineteen states in 1976, to twentyone states in 1987, thirty states in 1991 to the present thirty-six states and Federal Capital Territory (FCT) in 1996 a curse or a blessing?

From welfare and spatial development perspective, it was to get and enable equity in the distribution of resources, filtering down enabling services to the people and making participation all-inclusive to all Nigerians in the governance of the country without leaving out any of her multitude ethnic groups. From another perspective of uniting the people of varying backgrounds, the country may be failing; the country was not more divided than presently being experienced. This means that when the country operated three regions at independence all the north was one; all the west was one and all the east was one. The division of the country into state space does not at any point attracting self-determination or self-governance or insinuating secession. However, the demarcation and recognition of geopolitical zones in the body polity of Nigeria has created sense of togetherness and superior loyalty to each zone 
than to the country. For instance, the voting pattern at every election always reflects a spatial pattern influenced by the geopolitical zones of the country. Also, there is marked favouritism in terms of wealth distribution (resources and appointments) tilting disproportionately in favour of the zone in power in total jettisoning of federalism.

Ethno-religious conflicts have been identified as a major source of insecurity in Nigeria (Ibrahim \& Igbuzor, 2002; Hazen \& Horner, 2007; Salawu, 2010; Igbuzor, 2011). Multi-ethnic and multireligious society is characterised by lack of cordiality, mutual suspicion and fear, and a tendency towards violent confrontations to settle grievances. These conflicts have also revolved around who gets what and how in the state especially as it concerns the distribution of scarce resources, power, land, chieftaincy titles, local government councils, control of markets and expansion of religious territories. These conflicts have resulted in large-scale killings and violence among ethno-religious groups in the country (Adagba, Ugwu \& Eme, 2012).

According to Achumba, Ighomereho \& Akpor-Robaro (2013) insecurity is the antithesis of security which attracts such common descriptors as want of safety, danger, hazard, uncertainty, want of confidence, state of doubt, inadequately guarded or protected, instability, trouble, lack of protection and being unsafe among others. They submitted that all the descriptors point to a condition of vulnerability to harm, loss of life, property or livelihood. Therefore, they considered insecurity to be a state of not knowing, a lack of control, and the inability to take defensive action against forces that portend harm or danger to an individual or group, or that make them vulnerable. Beland (2005) described insecurity as "the state of fear or anxiety stemming from a concrete or alleged lack of protection." It refers to lack or inadequate freedom from danger. For Onifade, Imhonopi \& Urim (2013) insecurity is conceived as a situation where human and national security of a state is compromised by internal or external forces or interests exacerbated by the former's weak or poor economic, military and/or human resource development conditions. The general insecurity in Nigeria has been described as a decline in the security of the Nigerian nation-state likened to situation of the ruler and his immediate supporters, thus, the security calculus of the Nigerian state has failed. This state of inequality, unfairness and injustice has toughened the people, forcing them to take their destiny into their hands (Egwu, 2001). This may have captured the underline factor for the current (October, 2020), massive \#ENDSARS protest and conflagration across the country.

Onifade, Imhonopi \& Urim (2013) categorised the aetiologies of insecurity within Nigeria in twofold: remote and proximate causes. The remote factors include such causes as absence of institutional capacity resulting in government failure, what Fukuyama (2004) called the breakdown of institutional infrastructures i.e. the ineptitude of the government could be held for the breakdown of security in Nigeria system. Whereas, immediate and proximate factors according to Achumba et al. (2013) are factors that have contributed to the state of insecurity in the country which include porous borders, rural-urban drift, social irresponsibility of companies resulting in negative externalities which provoke social unrest within their host communities, unemployment, poverty and terrorism, among others.

The general geography of the country features the vegetation of Nigeria as forest and savannas. Southern Nigeria has mangrove and fresh water forest, tropical rain forest and guinea savannah with forest dominance. The northern Nigeria is covered by guinea savannah, sudan savannah and sahel savannah. This vegetation distribution is a response to rainfall distribution pattern in the country. However, there are intra-vegetation variations not captured in the above vegetation belts which now promote ungoverned space in Nigeria. Rainfall distribution is not uniform, same does the vegetation due to some geographical factors such as high altitude (promoting orographic rainfall), wind direction and more rain for areas lying on the moisture laden south west monsoon wind paths, and good edaphic factor may influence change thus, the occurrence of forest interspersing the savannas in different parts of northern Nigeria.

The rest of the paper discusses an insight into insecurity in northern Nigeria, causes, effects and pragmatic actions taken and attempts to chart a way-out of persistent insecurity in the northern geopolitical zones. Of recent the southern Nigeria could be said to experiencing relative peace, however, same could not be said of northern Nigeria since the forceful occupation of part of North East by the Boko Haram insurgency. The spate of violence in the northern Nigeria has reached a point which almost surpassing all forms of remedies, hence, the resolve to focus on the insecurity in the region. 


\section{INSIGHT INTO INSECURITY SCENARIO IN NORTHERN NIGERIA}

A concise highlight of the insecurity examine here showcase the security crisis in each of the geopolitical zones in the northern Nigeria.

The first zone examine is Northwest and according to International Crisis Group (ICG) (2020) the zone is suffering deadly conflict involving many armed organisations, including herder-allied groups, vigilantes, criminal gangs and jihadists. The violence has killed over 8,000 people since 2011, and displaced over 200,000, some into neighbouring Niger Republic. And for over four decades the zone has witnessed waves of violence including sectarian clashes, Islamist militancy and electoral violence. From 1980 to 2010, it saw numerous Christian-Muslim and intra-Muslim riots. Between 2011 and 2015, Kaduna and Kano states suffered many Boko Haram bombings and shootings (ICG, 2020). For instance, after 2011 presidential election lost by Muhammed Buhari started the protests in fourteen northern states which escalated into ethnic and sectarian riots and left over 1,000 people dead and 74,000 displaced. In southern Kaduna state, a decades-long contest between the Hausa and Fulani on one hand, and several smaller ethnic groups on the other, over political offices, economic resources and the fruits of government spending has resulted in recurrent violence, often with significant fatalities (ICG, 2020).

The violence affecting the zone is multi-faceted, but much of it can be divided among three major categories, which overlap in certain ways as follows. The first category includes violence pitting mainly ethnic Hausa sedentary farmers and vigilantes acting on their behalf against predominantly Fulani roving herders and associated militias. The zone has witnessed a surge in violence between pastoralists and allied armed groups frequently called "bandits", on one hand, and farmers supported by community and state-sponsored vigilantes, on the other. These militias/bandits operate in a largely decentralised manner under local commanders' autonomous control. They are motivated first and foremost by fighting on behalf of herders in their disputes with farmers, but many rogue elements have taken up criminal activities as well. The violence, largely occurring in rural areas and has spread from its epicentre in Zamfara state to Kano, Kaduna, Katsina, Kebbi and Sokoto states in the zone and into Niger state in North central Nigeria (ICG, 2020).

The second category involves violence committed by criminal gangs involved in large-scale cattle rustling, kidnapping for ransom, armed robbery, pillage, and attacks on gold miners and traders. The authorities sometimes also refer to these gangs as "bandits". These groups comprise a mix of individuals from Fulani, Hausa and other ethnic origins who seek to enrich themselves rather than to advance a political or ideological project. These groups do not operate like militias; they are neither cohesive nor under a centralised command. They also act autonomously, sometimes in rivalry with one another. Rustling activities have resulted in the theft of a huge number of cows, deaths of people and destruction of property. Cattle rustlings have significantly contributed to the increasing security challenges facing the Nigerian state and seem to have become big business involving the herders, bigtime syndicates, and heavily armed bandits (GIGA, 2016). Virtually all the states in the northern Nigeria are affected by cattle rustling which is very rampant in rural areas, it does not only pose serious security challenges at the specific sites of conflict but also threatens to engulf places outside of the rural sector.

Another notable violence root is kidnapping, violent robberies and killings linked to gold mining activities which has turned the zone into a fiefdom of deadly gangs. Criminal gangs have increasingly taken to attacking and robbing gold miners, particularly in Zamfara, which has seen an explosion in artisanal gold production at deposits scattered around the state. Gold is one of the most smuggled commodities in Nigeria and much of it is traded on the international market with hardly any contribution to the country's gross domestic product or to federally collected revenues. Artisanal mining also provided jobs and livelihoods for many rural people in these areas, attracting other miners from as far away as Mali, Burkina Faso, China and India, but it spawned an underground economy of smugglers, drug dealers and commercial sex workers (ICG, 2020). Attack on mining sites usually leads to killing of miners and stealing of their precious stones, money and mining tools. The illegally mined gold are sometimes transported through the largely unsecured borders into neighbouring countries such as Niger Republic, where it is traded for money, weapons and ammunitions (WANEP, 2020). A third layer of violence in Northwest involves Islamist militant groups (Jihadists) which infiltrated and linked to the original Boko Haram insurgency in 2019 (ICG, 2020). 
The tactical use of difficult inaccessible operational terrains to state security such as the use of Falgore, Kamara, Kunduma, Sububu, Kamuku and Kiyanbana forests by bandits, which enable them quick retreat and buffer for their attacks within the axis of their operations. In the light of this, the exigencies of banditry, insurgency and counter-insurgency have transformed the forests areas into highly militarized and securitized zones, stalling socio-economic development in the zone (WANEP, 2020). The security challenges pose to the troop are lack of motorcycles needed to travel on such terrains which are impassable for cars and trucks; and lack of sufficient helicopters to deploy troops rapidly to remote locations in fighting insecurity in the northern zones. Also, boom of trade in small arms and light weapons in the region and organised gangs operating from ungoverned forests engage in cattle rustling, kidnapping for ransom and armed robbery, including of miners and traders in the largely unregulated gold mining sector and pillage of communities (ICG, 2020) have exacerbated insecurity in the zone.

The main weapons used in Nigeria's herder-farmer violence, and their supply routes include factoryproduced small arms manufactured in Europe, East Asia, the Middle East and North America; there are prevalence of Chinese Type 56-2 7.62×39 mm assault rifles; and major international smuggling routes for weapons include Libya, Turkey and Côte d'Ivoire. They have also procured weapons from other armed groups in north-eastern Nigeria, the Boko Haram offshoot, the Islamic State in West Africa Province (ISWAP) and from corrupt government security personnel, gun importers in southern Nigeria and local gunsmiths (ICG, 2020).

The second zone is the Northeast where Boko Haram and Ansaru operate as terrorist organizations with a radical Islamic agenda with territorial ambitions to create a radical state governed by Shariah. Boko Haram $(\mathrm{BH})$ has declared a jihad. Its first attack was a prison break which took place in September 2010 when President Umaru Yar'Adua dies and Goodluck Jonathan becomes president. Insurgency peaked in Northeast with the assassinations of Muslim leaders, bank robberies, bombings of government buildings particularly, when election voting brought Goodluck Jonathan into office in 2011 with insurgents continued conquering territory. However, in 2015 when Muhammadu Buhari was elected as Nigerian president, he was able to reclaimed much of the territory from Boko Haram and the insurgents restricted to around Lake Chad, southern Borno, and eastern Yobe (The World Bank, 2018). Boko Haram have perpetuated violent high-fatality attacks on markets, schools, government establishments and both Christian and Muslim places of worship (Africa Growth Initiative, 2014). Actually, the group was radicalized in 2009 when its leader at that time, Mohammed Yusuf was killed following a government clampdown on the group that resulted in the death of about 800 people (Adibe 2011). The other group, Ansaru's activity was heaviest in Kano state, where the group appears to have an operating base (Africa Growth Initiative, 2014). Adamawa, Borno and Yobe states have the highest intensity of violence in this zone with Borno state at forefront (Africa Growth Initiative, 2014). According to The World Bank (2018) households in the zone are the most exposed to all types of conflict events, $49 \%$ of households have experienced at least one event of conflict or violence against a household member, more than two-thirds of conflict events in the zone were caused by Boko Haram. The most affected groups are women, children, and youth.

Boko Haram's tactics have included multiple modes of attack in form of suicide bombings, seizure and destruction of entire villages, forced displacement, abductions, sexual violence targeting women, and forced recruitment of men (The World Bank, 2018). It has conducted terrorist attacks on religious and political groups, local police, and the military, and indiscriminately attacking civilians in busy markets and villages (Human Rights Watch, 2019, Global Conflict Tracker, 2020).

The third zone is the North central which according to The World Bank (2018) is characterised by conflict and violence events, $25 \%$ of households have experienced any type of conflict event and more than half of all reported conflict events were caused by disputes over access to land or resources, $33 \%$ of conflict-affected households had at least one member displaced. In recent years, conflict in the zone has both escalated and expanded as tensions between farmers and herders have risen. The conflict usually centred on agricultural households and nomadic cattle-herding groups who come into conflict over land access. Also, population increase has caused increases in the amount of land use for farming extending often into areas that have traditionally served as cattle grazing areas. In addition, climate change and the Boko Haram insurgency have reduced the amount of land suitable for grazing, forcing herding communities to expand their routes into increasingly Southern areas. This competition over land and resources is compounded by religion and ethnicity (The World Bank, 2018). Plateau 
state has experienced very high levels of conflict in this zone, but the incidents are most frequently long-standing ethno-religious (Africa Growth Initiative, 2014) which has claimed numerous lives of Nigerians and property worth millions of naira through several attacks on Christians by Muslims. Not much is being done by the government to stop the callous killing because the government knows those behind all these riots, those importing arms into this country (Nwagboso, 2010). Cases of reprisal attacks are common, for instance, a case of farmers allegedly killed five herdsmen for allegedly trespassing on farms was follow with retaliation in which herdsmen attacked villages in the area (Plateau state), killing 86 and injuring hundreds, including women and children; and in September, suspected herdsmen killed 51 people and abducted about 24 others in Numan, Adamawa state. The zone has also witnessed cattle-rustling increases, estimated as 60,000 cattle stolen in 2013 (HRW, 2019).

\section{CAUSES OF INSECURITY IN NORTHERN NigERIA}

Many observers state that Nigeria's failed institutions are the driving force behind the acts of violence by Boko Haram and Ansaru (Africa Growth Initiative, 2014). Of violence in Northeast terrorism accounts for $73 \%$; land or resource access $7 \%$; cultism or criminality $15 \%$ and ethnicity, politics, or religion 5\%. Violence in the North central zone has been attributed to terrorism 21\%; land or resource access 55\%; cultism or criminality $16 \%$ and ethnicity, politics, or religion $7 \%$ (The World Bank, 2018).

Violence is rooted in competition over resources between predominantly Fulani herders and mostly Hausa farmers. It has escalated amid a boom in organised crime, including cattle rustling, kidnapping for ransom and village raids (ICG, 2020); and weakly regulated international boundary. Historical and cultural ties between communities on both sides of international boundary and regional protocols on freedom of movement have exacerbated smugglers and criminals' activities. Illegal crossings, coupled with pervasive corruption among border officials enable the traffic of illicit merchandise such as firearms (ICG, 2020) and the lack of state government leadership also plays a key role in escalating and spreading of violence (ICG, 2020).

Another factor is the changes in climatic and environmental conditions and rising demographic pressures. The far north has experienced a substantial shortening in the length of the rainy season in recent times. Diminishing water sources and an increase in desert or semi-desert conditions have shrunk both arable land and pasture. Also, the region's rapidly growing population has also increased demand for available land. The desertification and the population growth intensify competition for territory suitable for farming and grazing. Also important is the controversial government policies allocating land to farmers at the expense of herders which have worsen the situation resulting in encroachment on and blockage of livestock grazing routes and necessitating demands for compensation for damaged crops. The herders have severally protested the compensation they had to pay thus the stage set for confrontation and violence (ICG, 2020).

The formation of vigilante groups, referred to as yan sa kai (volunteer guards), to protect farmers and their villages became another source of insecurity. The groups use locally made guns, machetes, clubs and other crude weapons and meted out harsh sanctions to real or perceived perpetrators of robberies and raids. Their sanctions include arbitrary arrests, torture, indiscriminate confiscation of cattle and extrajudicial killings with suspects sometimes hacked to death in markets and other public places. Its consequential effect was the formation of counter-groups, militia groups, known as yan-bindiga (gun owners) to protect herders and their cattle and to avenge vigilante atrocities. Militia groups were better funded for arms acquisition from a combination of community contributions and a range of other activities such as kidnapping for ransom (ICG, 2020).

The region's geography and climatic conditions pose serious challenges for federal and state authorities because much of the Northern zones is savannah interspersed with vast forests, some of which are home to thousands of mostly Fulani herders (ICG, 2020). Onifade, Imhonopi \& Urim (2013) described this as complicated where exist large unregulated and poor government-controlled forest areas, some of which are situated within under-policed border areas between Nigeria and neighbouring countries, thus, aiding cross-border criminality. They observed that majority of the farming communities have been forced to abandon their farms especially in areas in proximity to the forest areas, and few farmers who stayed behind have been subjected to taxation by the bandits before 
accessing their farms. Also, weak regulation of pastoral activities in the forests has encouraged the infiltration of livestock bandits in large scale cattle rustling (WANEP, 2020).

Onifade, Imhonopi \& Urim (2013) summarised the factors that drive banditry in the northern Nigeria as cattle rustling, illicit artisanal gold mining, proliferation of Small Arms and Light Weapons (SALW), youth unemployment, inequality and poverty, weak governance and security capacities. The causes of insecurity according to them also include increasing ethnic hate, religious bigotry, political rivalry and a growing population of disgruntled citizens in the country who feel that they have been short-changed and given very limited or no access to the common patrimony.

\section{EFFECT OF INSECURITY IN NORTHERN NIGERIA}

The effects of insecurity in northern Nigeria is multidimensional and multifaceted, some of which are examined in this subsection.

Conflicts have disrupted the supply and distribution of inputs and outputs in agriculture production thus create price shocks and cause massive displacement of labour, which makes agricultural investments difficult to maintain in politically volatile environments. Messer, Cohen \& D'Acosta (1998) estimated that conflict has affected agricultural production to drop by an average of 12.3 percent each year. Nigeria's foreign direct investment also dropped 23 percent from 2011 to 2012, and this drop has been attributed to the activities of Boko Haram and Ansaru. Among factors account for decline in agriculture is the reduction in the availability of labour due to the threat of attacks on farmers on their way to the fields. Also, both traders and consumers restricted their movements to markets due to intermittent attacks and fear of attack has displaced people outside the conflict zone, further reducing labour pools (Africa Growth Initiative, 2014, ICG, 2020). Africa Growth Initiative (2014) summarised the conflict effects on agriculture due to the fear and risk of insurgents attack into four: reduced human mobility; reduced access to inputs and markets; increased theft of various assets; and increased prices of inputs and products. Commerce has been similarly disrupted as thousands of shops and other businesses in northern Nigeria are in ruins or shut down due to direct attacks and kidnappings of businessmen (ICG, 2020). Bandits' attacks on communities have increased social risks, discouraged investment and triggered economic crises for individuals and communities, hindering inter-communal and inter-state trade. A number of major local markets such as IIella, Dandume, Maidabino, Kankara (Katsina State) and Bardoki, Shinkafi (Zamfara State) markets have been shut down due to incessant attacks (WANEP, 2020, Onifade, Imhonopi \& Urim, 2013).

The violence has claimed thousands of lives over the last decade and hundreds of thousands of people have been displaced. UN High Commissioner for Refugees and the National Commission for Refugees, Migrants and Internally Displaced Persons (IDPs) estimated 210,354 persons displaced from 171 towns and villages in the Northwest (ICG, 2020). Majority of these IDPs were women, children and the elderly taking refuge in neighbouring Republic of Niger, Cameroun and Chad (WANEP, 2020). The crisis has had gender-differentiated effects on thousands of men and boys kidnapped or killed and robbed of their cattle or possessions, leaving thousands of women as both widows and sole remaining breadwinners and many children have been orphaned. Women and girls have also been targeted for attacks; kidnapped and raped, sexually assaulted during raids or forced into "marriage". The criminal activity has swelled the already high number of out- of-school children in northern Nigeria, thus the surge in number of child street beggars in many towns and cities (ICG, 2020, Onifade, Imhonopi \& Urim, 2013, WANEP, 2020).

The infiltration of herders, fleeing violence north and migrating southward is already straining resources in the southern zones. There have been uptick and exacerbating tensions in the south east, south west and Niger Delta, with increasing herder-farmer friction, often degenerating into deadly violence. For instance, southwest geopolitical zone governors have established the Western Nigeria Security Network referred to as Operation Amotekun, on 9 January 2020, to protect their communities (ICG, 2020).

\section{ACTION TAKEN TO CURTAIL INSECURITY}

Government has tried everything from "force-for-force" to carrot-and-stick approach to diplomacy. There has also been strong advocacy for a multi-stakeholder intervention to address insecurity rather than lean on military options alone (Imhonopi \& Urim, 2012, Open Society, 2012, Ujomu, 2001). The federal government's attempts to contain armed groups in the North have largely depended on the 
security forces primarily through military and police operations (ICG, 2020, WANEP, 2020). The federal government has adopted banning of the use of motorcycles within the hinterland and forests and suspension of all mining activities to deal with illicit gold mining (WANEP, 2020). The government has also sought closer security cooperation with neighbouring countries and with the assistance of Benin, Cameroon, Chad, and Niger, has successfully reclaimed the territory ceased by Boko Haram (Global Conflict Tracker, 2020).

The state governments in the northern zones have responded to increasing violence mostly by supporting federal security agencies with funds and logistics to fight the armed groups. They sought counter attacks by herder-allied groups and criminal gangs by forming and empowering vigilantes to protect communities. They later changed tactics in curbing the violence to negotiating peace agreements with herder-allied armed groups and criminal gangs through such strategies as amnesty, arms-for-cash programs and promises of spending for local communities, in return for disarmament, pledge to disarm and disband vigilante groups, rehabilitation and reintegration of herder-allied and other armed groups willing to lay down their arms, and promises to establish rural grazing areas including settlements with social amenities (ICG, 2020, WANEP, 2020). The governments also agree to release all former armed elements in custody in exchange for all persons the herders are holding in their forest camps, recruitment of youths for skills training that would equip them for paid employment or to become self-reliant entrepreneurs (ICG, 2020). Use of integrative response approaches involving security agencies, traditional, religious leaders, Hausa/Fulani community, Miyetti Allah Cattle Breeders Association (MACBAN), Farmers Associations and local vigilante groups (Onifade, Imhonopi, \& Urim, 2013, WANEP, 2020). The use of community watch groups to complement other groups for intelligence gathering to secure communities (WANEP, 2020) and the use of Joint Task Force made up of the police force, the military and civilians who provide intelligence (IISS 2013) and the declaration of emergency in some states, with intermittently cut off cell phone coverage to dismantle terrorist communication (Africa Growth Initiative, 2014).

\section{Prospect For Peaceful and Secured Northern Nigeria}

The concentration of security basically in the cities for the protection of men and properties, is quite inadequate, leaving out the rural space and forest as den for rogue and banditry. Violence moves the nation nowhere and its effect may go beyond stagnation but backwardness in human and material development, thus the need to chart the way forward. It can be deduced from foregoing that there is poor understanding of the country's geography which has been downplayed in the security architecture of the country, which poses much danger. The general belief that the northern geopolitical zones are covered by savannas is no longer tenable, arrangement should be made to govern and secure the forest and conservations through the use of armed forest guards, well equipped with modern digital communication technology adequately network with police and military for prompt response which could make policing all embracing, encompassing and comprehensive in Nigeria environment. There is need for the country to prioritise the acquisition of more helicopters for military use in this respect. It is thus necessary to make geography a compulsory subject in schools for all students to ensure better understanding of Nigeria environment.

Constitution of Nigeria should make operational the existing six geopolitical zones of the country to encourage and facilitate cooperation among the states in each zone for a formidable security outfit without any threat to national unity. More strategic plan should be evolved to put an end to pastoralism in the country because it has adverse effect on food production and has done more harm in ruin famers' fortune. There should be law to prohibit freely carrying and use of arms and dangerous weapons such as gun, swords, machetes, cutlass, and knife around settled spaces by the citizens.

One of the ways to restrict interaction and curtailing movement between two cultures, nations or countries is construction of physical barrier. It is essential to construct an artificial barrier on the international borders in the northern Nigeria. Although this may look hard for the current president because of his plan to consolidate interaction with Niger Republic through rail linkage. However, this is crucial to assure national security and to stop arms importation, criminal infiltration and to curtail economic loss of all forms.

Strategic spatial planning of each state should be given priority such that each land use is allotted a designated space to curb the indiscriminate development especially around the cities. This will put under control the indiscriminate and dangerous exposure of the environment to climate change 
adverse effect. This should be complemented by afforestation and reafforestation so as to replenish the environment and be sure of its safety.

Education sector could be re-engineered to improve social and spatial interaction among Nigerians through tertiary institutions' distribution that make them specialise in different field of specialization to facilitate inter-state and inter-regional patronage and mix the ethnics and tribes. This will enable better understanding and facilitate cordial relationship in complementing the existing national youth service.

\section{CONCLuSion}

The insecurity in northern Nigeria has touched every geopolitical zone in the area and characterised by herder-farmer criminality, cattle rustling, kidnapping, armed robbery, pillage, forced displacement, abductions and sexual violence, illicit artisanal gold mining, proliferation of Small Arms and Light Weapons (SALW), ethnic hate, religious bigotry, political rivalry and a growing population of disgruntled citizens. And the major actors are Boko Haram, farmer - herder criminality, terrorism and banditry, criminal gangs and jihadists crime as well as aggrieved people. All these have had adverse effects on agriculture, investment, increasing out-of-school children, displacement of people and curtailing of economic activities. Government efforts at federal and state levels have not completely end the insecurity in northern Nigeria, thus necessary to chart a new way to secure the region. It is therefore recommended that there should be well equipped armed forest guards with modern digital communication technology, operational of geopolitical zones as basis for planning policing, construction of physical barriers on the international borders, strategic spatial planning, and adoption of afforestation and reafforestation to cushion the effect of climate change.

\section{REFERENCES}

Achumba, I. C., Ighomereho, O. S. \& Akpor-Robaro, M. O. M. (2013). Security challenges in Nigeria and the implications for business activities and sustainable development. Journal of Economics and Sustainable Development, 4(2), 79-99.

Adagba, O., Ugwu, S. C. \& Eme, O. I. (2012). Activities of Boko Haram and insecurity question in Nigeria. Arabian Journal of Business and Management Review, 1, 77-99.

Africa Growth Initiative (2014). The impact of conflict and political instability on agricultural investments in Mali and Nigeria. Africa Growth Initiative Working Paper 17.

Beland, D. (2005). The political construction of collective insecurity: From moral panic to blame avoidance and organised irresponsibility. Center for European Studies Working Paper Series 126.

Egwu, S. G. (2001). Ethnic and religious violence in Nigeria. Jos, St. Stephen Book House.

Fukuyama, F. (2004). State-building: Governance and world order in the $21^{\text {st }}$ Century. Ithaca, Cornell University Press.

German Institute for Global and Area Studies (GIGA) (2016). Cows, bandits, and violent conflicts: Understanding cattle rustling in northern Nigeria. Afrika Spectrum: Deutsche Zeitschrift fur Gegenwartsbezogene Afrikaforschung, 51(3), 93-105.

Global Conflict Tracker (2020). Boko Haram in Nigeria. Council on Foreign Relations.

Hazen, J. M. \& Horner, J. (2007). Small arms, armed violence, and insecurity in Nigeria: The Niger Delta in perspective. Switzerland, Small Arms Survey.

Ibrahim, J. \& Igbuzor, O. (2002). Memorandum submitted to the Presidential Committee on national security in Nigeria.

Igbuzor, O. (2007). Peace and security education: A critical factor for sustainable peace and national development. International Journal of Peace and Development Studies, 2(1), 1-7.

Imhonopi, D. \& Urim, U. (2012). The spectre of terrorism and Nigeria industrial development: A multistakeholder imperative. The paper was prepared for the Nigerian Anthropological and Sociological Association (NASA) Conference with the theme" Theoretical and Conceptual Issues on social values and security" held at the Nnamdi Azikwe University, Akwa, Anambra State between November 5-9, 2012.

Human Right watch (2019). World report 2019 Nigeria events of 2018. Human Right Watch.International Crisis Group (2020). Violence in Nigeria’s North West: Rolling Back the Mayhem. Africa Report $N^{\circ} 288$.

Messer, E., Cohen, M. J. \& D'Costa, J. (1998). Food from peace: Breaking the links between conflict and hunger. International Food Policy Research Institute (IFPRI). 
Onifade, C., Imhonopi, D. \& Urim, U. M. (2013). Addressing the insecurity challenge in Nigeria: The imperative of moral values and virtue ethics. Global Journal of HUMAN SOCIAL SCIENCE Political Science, 13(2).

Open Society Initiative for West Africa (2012). Nigeria ensuring stability, human safety and security. Briefing Paper, October 2012.

Salawu, B. (2010). Ethno-religious conflicts in Nigeria: Causal analysis and proposals for new management strategies. European Journal of Social Sciences, 13(3), 345-353.

Ujomu, P. O. (2001). National security social order and the quest for human dignity in Nigeria: Some ethical considerations. Nordic Journal of African Studies, 10(2), 245-264.

WANEP (2020). Addressing armed banditry in the North-West region of Nigeria: Exploring the potentials of a multi-dimensional confict management approach. West Africa Network for Peacebuilding.

The World Bank (2018). Conflict and Violence in Nigeria Results from the North East, North Central, and South South zones. National Bureau of Statistics, Nigeria.

Citation: Jubril Babatunde, Jimoh. . “Geography and Insecurity in Northern Nigeria”International Journal of Research in Geography. vol 6, no. 2, 2020, pp. 43-51 doi: http://dx.doi.org/10.20431/2454-8685.0602005.

Copyright:(C) 2020 Authors. This is an open-access article distributed under the terms of the Creative Commons Attribution License, which permits unrestricted use, distribution, and reproduction in any medium, provided the original author and source are credited. 